\title{
Study on Implementation of Integrated Curriculum in Indonesia
}

\author{
Erwin Akib1, Muhammad Erwinto Imran², Saiyidah Mahtari³, Muhammad Rifqi Mahmud4, \\ Anggy Giri Prawiyogy ${ }^{5}$, Irfan Supriatna ${ }^{6}$, MT. Hartono Ikhsan ${ }^{7}$ \\ 1,2 Muhammadiyah University of Makassar, Makassar, Indonesia \\ ${ }^{3}$ Lambung Mangkurat University, Banjarmasin, Indonesia \\ 4UIN Sunan Gunung Djati, Bandung, Indonesia \\ ${ }^{5}$ Buana Perjuangan University, Karawang, Indonesia \\ 6University of Bengkulu, Bengkulu, Indonesia \\ 7STKIP Sebelas April, Sumedang, Indonesia
}

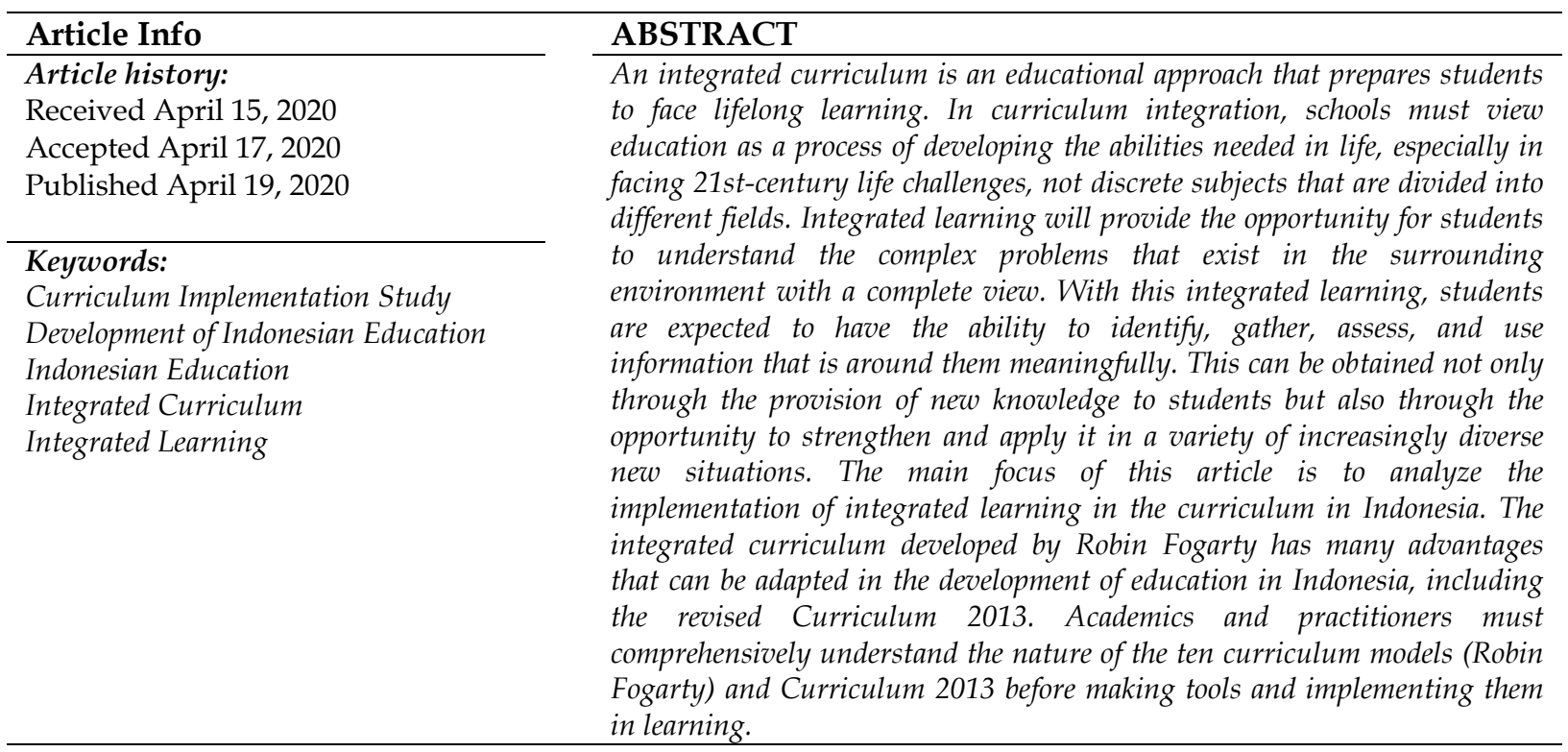

\section{INTRODUCTION}

Education is part of a fundamental aspect of life for the national development of a country. The quality of education is very influential in the progress of the nation and state. Education is said to be of quality or quality if the learning process takes place effectively, students show high mastery of the material, gain meaningful experience for themselves, according to the needs of students in their lives, and educational products are individuals who benefit the community and nation-building. Therefore, the government is always trying to improve the quality of education, including by issuing various laws and regulations, one of which is the National Education Standards. The existence of these content standards, reflecting that the design and implementation of the curriculum were submitted by the education provider (school), and in the guidelines issued by the BSNP, it has been said that the curriculum structure for the elementary level is determined by learning in grades I through grade III. Through a thematic approach, which means integrated learning, while grades IV through grade VI are implemented through a subject approach.

However, the substance of social studies and science subjects is integrated learning. Likewise, the substance of social science and science subjects of junior high level is also 
integrated. Therefore, teachers, school principals, and parties related to the implementation of learning in schools must be able to understand what an integrated curriculum is and how it is implemented. Understanding of the integrated approach will be able to support the implementation of meaningful learning. In this case, the learning experience of students will be more complete and oriented to competence. However, the facts on the ground show that learning is more teacher-centered; children's learning experiences are incomplete and are not competent oriented. Besides, students are not accustomed to developing their potential, so many students tend to be lazy to think independently. The way of thinking developed has not touched the affective and psychomotor aspects.

There have been many studies on integrated curicullum (Costley, 2015; Draghicescu et al., 2013; Drake \& Reid, 2010; Fogarty \& McTighe, 2015; Kim \& Aktan, 2014; Kiray, 2012; Kurt \& Pehlivan, 2013; Mc Bee, 2016; Supriatin, 2008). Including the many studies related to Integrated Science learning (Duiningrum, 2018; Ekapti \& Ahied, 2016; Hapsari, et al., 2013; Hasnawati, 2013; Mansurotun et al., 2014; Muhafid \& Dewi, 2013; Makhrus \& Hadi, 2012; Puspita \& Widodo, 2013; Rahmanto \& Masykuri, 2015; Rahmatika, 2016; Rahmatika \& Ismono, 2013; Sukartiningsih, 2016; Wiyono, 2013). Integrated learning will make connections between concepts both inter and between subjects. The integrated relationship between concepts will facilitate students to be actively involved in the learning process and encourage students to understand the concepts they learn through direct experience and relate them to real experiences. Integrated learning as a concept is a learning approach that involves several subjects to provide meaningful learning experiences for children. Integrated learning is believed to be an approach that is oriented towards learning practices that are appropriate to the child's needs. Effective integrated learning will help create broad opportunities for students to see and build interconnected concepts. Thus, student learning outcomes may be more meaningful than if only through a drill in responding to signs or signals from the teacher given separately. This is following what was said by Zais (1976) that integrated learning provides an overview of how the learning experience of students in an integrated manner gives a meaningful impact and how integration is done. Just as is necessary for each subject to be treated as an integrated whole in a gestalt based curriculum, so all the subjects of the curriculum need to be related so that the learner's educational experiences result in coherent and meaningful Gestalt (Zais, 1976).

Based on the description above, it can be said that integrated learning will provide an opportunity for students to understand the complex problems that exist in the surrounding environment with a complete view. With this integrated learning, students are expected to have the ability to identify, gather, assess, and use information that is around them meaningfully. This can be obtained not only through the provision of new knowledge to students but also through the opportunity to strengthen and apply it in a variety of increasingly diverse new situations. Therefore, the purpose of this article is to:

- Analyze integrated curriculum development.

- Analyze the basic principles of integrated learning.

- Analyzing the characteristics of integrated learning.

- Analyzing the foundation of philosophy and psychology of integrated learning.

- Analyzing the development and implementation of integrated learning.

- Analyzing the strengths and weaknesses of integrated learning.

- Analyzing the implementation of integrated learning in the curriculum in Indonesia. 


\section{DISCUSSION}

\section{Integrated Curriculum Development}

Before discussing the integrated curriculum, it is necessary to define in advance what the integrated curriculum is. Shoemaker defines an integrated curriculum as follows: ".... education is organized in such a way that it crosses subject boundaries, combining various aspects of the curriculum into meaningful associations to focus on in the wider study area" (Indrawati, 2009). This curriculum views learning and teaching holistically and reflects the real interactive world. Furthermore, Palmer (1991) has described practices in implementing an integrated curriculum, namely:

- Develop cross-curriculum sub-objectives within the existing curriculum guide.

- Develop learning models that include cross-curriculum activities and assessments.

- Develop enrichment and activity enhancements with a cross-curriculum focus that includes cross-curriculum "contact" suggestions at each destination.

- Develop cross-curriculum assessment activities, including sample planning in all curriculum guides.

Further description, revealed by Glatthorn (1994) that in the integrated curriculum, planned learning experiences not only equip students with an integrated view of general knowledge (through learning models, systems, and cultural structures) but also motivates and develops the power of learners to understand new relationships and create new models, systems and structures.

Besides, various concepts of cohesiveness have also been put forward by several experts, including Tyler, who argue that "... Integration as the horizontal relationship of curriculum experiences ", and the benefits of cohesiveness according to Taba (Olivia, 1992) are" ... learning is more effective when facts in principles from one field can be related to another, especially when applying this knowledge ... ". Learning will be more effective if the teacher can connect or integrate the implementation of learning in school with the findings in the field. Therefore, concerning the integrated curriculum, the task of the teacher, according to Olivia (1992), is "... curriculum workers should concern themselves with the problem of integrating subject matter". Thus, the teacher can integrate subject matter in learning with the student's living environment.

The definitions above contain the understanding that an integrated curriculum is an educational approach that prepares students to face lifelong learning. There is a strong belief among those who support curriculum integration that schools must view education as a process of developing the skills needed in life, especially in facing life challenges in the 21st century, not discrete subjects that are divided into different departments. Therefore, the definition of an integrated curriculum or interdisciplinary curriculum in general includes:

- Combination of subjects

- Emphasis on project

- Sources outside the textbook

- Linkages between concepts

- Thematic units as organizational principles

- Flexible schedule

- Flexible grouping of students

Furthermore, figures such as Collin \& Dixen (1991) argue that: "Integrated learning occurs when an authentic event or exploration of a topic is the driving force in the 
curriculum." Integrated learning is an activity that takes place in a real way, and the investigation of topics is directed to strengthen the curriculum. Fogarty (1991) describes the existence of ten levels of curricular integration in Table 1.

Table 1. Variety of Integrated Curriculum Models.

\begin{tabular}{|c|c|c|c|}
\hline Model & Description & Advantages & Disadvantages \\
\hline Fragmented & $\begin{array}{l}\text { Various and separate } \\
\text { disciplines }\end{array}$ & $\begin{array}{l}\text { There is clarity and } \\
\text { separate views in a subject }\end{array}$ & $\begin{array}{l}\text { Connectedness } \\
\text { becomes } \\
\text { unclear, fewer transfers } \\
\text { of learning }\end{array}$ \\
\hline Connected & $\begin{array}{l}\text { Topics in one } \\
\text { scientific disciplines are } \\
\text { related to each other }\end{array}$ & $\begin{array}{l}\text { The main concepts are } \\
\text { interconnected, leading to } \\
\text { repetition, reconceptualization, } \\
\text { and assimilation of ideas in a } \\
\text { discipline }\end{array}$ & $\begin{array}{l}\text { Disciplines are not } \\
\text { related, the content } \\
\text { remains focused on one } \\
\text { discipline }\end{array}$ \\
\hline Nested & $\begin{array}{l}\text { Social skills, thinking, } \\
\text { and content are } \\
\text { achieved in one subject }\end{array}$ & $\begin{array}{l}\text { Pay attention to a variety of } \\
\text { different subjects at the same } \\
\text { time, enrich, and expand } \\
\text { learning. }\end{array}$ & $\begin{array}{l}\text { Students can be } \\
\text { confused and lost } \\
\text { direction about the } \\
\text { main concepts of } \\
\text { activity or learning. }\end{array}$ \\
\hline Sequence & $\begin{array}{l}\text { Existing equations are } \\
\text { taught simultaneously, } \\
\text { although included in } \\
\text { different subjects. }\end{array}$ & $\begin{array}{l}\text { Facilitate transfer learning } \\
\text { across several subjects. }\end{array}$ & $\begin{array}{l}\text { It requires continuous } \\
\text { collaboration and high } \\
\text { regularity because } \\
\text { teachers have little } \\
\text { autonomy to arrange } \\
\text { curricula. }\end{array}$ \\
\hline Shared & $\begin{array}{l}\text { Team planning and or } \\
\text { teaching involving two } \\
\text { disciplines focused on } \\
\text { the same concepts, } \\
\text { skills, and attitudes. }\end{array}$ & $\begin{array}{l}\text { There is experience-joint } \\
\text { instructional experience, with } \\
\text { two people teachers in a team, } \\
\text { it is easier to collaborate. }\end{array}$ & $\begin{array}{l}\text { It takes time, flexibility, } \\
\text { commitment, and } \\
\text { compromise. }\end{array}$ \\
\hline Webbed & $\begin{array}{l}\text { Thematic teaching, use } \\
\text { a theme as a basis for } \\
\text { deep learning various } \\
\text { subject disciplines. }\end{array}$ & $\begin{array}{l}\text { It can motivate the participants' } \\
\text { students, help students to see } \\
\text { the connection between ideas. }\end{array}$ & $\begin{array}{l}\text { The theme used must } \\
\text { be chosen carefully, } \\
\text { selectively, so that it } \\
\text { becomes meaningful } \\
\text { too relevant to the } \\
\text { content. }\end{array}$ \\
\hline Threaded & $\begin{array}{l}\text { Social skills, thinking, } \\
\text { various types of } \\
\text { intelligence, and } \\
\text { learning skills are } \\
\text { stretched through } \\
\text { various disciplines. }\end{array}$ & $\begin{array}{l}\text { Students learn how they learn, } \\
\text { facilitating the transfer of } \\
\text { further learning. }\end{array}$ & $\begin{array}{l}\text { The disciplines } \\
\text { concerned remain } \\
\text { separate from each } \\
\text { other. }\end{array}$ \\
\hline Integrated & $\begin{array}{l}\text { In various priorities that } \\
\text { overlap in various } \\
\text { disciplines, look for the } \\
\text { same skills, concepts, } \\
\text { and attitudes. }\end{array}$ & $\begin{array}{l}\text { Encourage students to see the } \\
\text { interrelationships and } \\
\text { interconnections between } \\
\text { scientific disciplines; students } \\
\text { are motivated by seeing the } \\
\text { various linkages. }\end{array}$ & $\begin{array}{l}\text { Requires interagency } \\
\text { team departments that } \\
\text { have the same planning } \\
\text { and teaching time. }\end{array}$ \\
\hline Immersed & $\begin{array}{l}\text { Students integrate what } \\
\text { they learn by looking at } \\
\text { the entire lesson }\end{array}$ & $\begin{array}{l}\text { Integration takes place within } \\
\text { the students themselves. }\end{array}$ & $\begin{array}{l}\text { It can narrow the } \\
\text { student's focus. }\end{array}$ \\
\hline
\end{tabular}




\begin{tabular}{clll}
\hline Model & \multicolumn{1}{c}{ Description } & \multicolumn{1}{c}{ Advantages } & Disadvantages \\
\hline & $\begin{array}{l}\text { through the perspective } \\
\text { of their preferred field. }\end{array}$ & \\
Networked & $\begin{array}{l}\text { Students do the process } \\
\text { integration of topics } \\
\text { learned through the } \\
\text { selection of expert } \\
\text { networks and resources. }\end{array}$ & $\begin{array}{l}\text { Be proactive; students } \\
\text { stimulated by information, } \\
\text { skills, or new concepts. }\end{array}$ & $\begin{array}{l}\text { Can divert attention } \\
\text { students; efforts become } \\
\text { ineffective. }\end{array}$ \\
\hline
\end{tabular}

\section{Basic Principles of Integrated Learning Understanding Integrated Learning}

Learning is designed to provide learning experiences that involve mental and physical processes through interactions between students, students, and teachers, the environment, and other learning resources to achieve basic competencies (BNSP, 2006). Hamzah argues that planning is a satisfying way to make an activity work well, accompanied by various anticipatory steps to minimize the gaps that occur so that the activity achieves the stated goals (Indrawati, 2009). Based on these opinions, the learning plan is a program of how to organize learning, convey learning content, and how to organize interactions between learning resources, learning tools, and students to achieve the goals set.

In addition to increasing the efficiency of the delivery of educational programs, the formalization of the school system in modern societies, which is characterized by the division of labor (specialization), also has serious side effects, especially for students at the elementary school level. If at a higher education level, the treasury of human knowledge can be sorted out for the efficiency of its presentation (mathematics, language, natural sciences, etc., which are taught separately by the teachers in the field of study), at the elementary school level, more in the early classes, students who still more fully experience their experience as a totality, have difficulty with the sorting of experiences that are "artificial." In other words, young students see themselves as the center of the environment which is a whole whose elements are not yet clear, with a holistic meaning that departs from concrete matters (Tisno \& Ida, 2007) This is supported by the opinion of a psychologist Jean Piaget who argues that the ability to associate with more abstract things that are needed to digest ideas in various academic subjects is generally only formed at the age when students sit in the last grade in elementary school and develop further with increasing age. If they have been able to handle these more abstract concepts, they are in a position to digest the selection of the environment in more detail, including the selection of subject matter based on the boundaries of the field of study, which requires the ability to think abstractly.

Starting from this opinion, then the way of packaging learning experiences designed for students will significantly affect the meaningfulness of the experience for them. Learning experiences that show the relationship of conceptual elements, both inter and between fields of study, will increase opportunities for more effective learning. That is, conceptual links from what is being learned with more and more sides in the same field (conceptual links intra-field of study, such as floods and erosion), and even with other fields (conceptual links between fields of study, such as floods with economic activity), are increasingly internalized by students. In other words, a learning experience that shows more of the relationship of conceptual elements will increase the opportunities for more effective learning. In other words, integrated learning aims to make learning, 
especially in elementary schools, more effective and realistic. Therefore, in learning, the teacher must make a learning plan.

Integrated learning is an activity that takes place in a real way, and the investigation of topics is directed to strengthen the curriculum. Another opinion says the integrated learning approach is a learning design that presents learning materials in an integrated way, namely by uniting, connecting or linking the learning material so that nothing is independent or separate (Indrawati, 2009). From some of the opinions above it can be concluded that the integrated learning approach is learning that starts from a particular subject or theme that is associated with other subjects, certain concepts are linked to other concepts, which are carried out spontaneously or planned, both in one field of study or more and with a variety of children's learning experiences, learning becomes more meaningful.

In the end, it can be said that integrated learning is a learning pattern or series of learning that allows students both individually and in groups to actively seek, explore and discover scientific concepts and principles holistically, meaningfully, and authentically. Advanced learning will occur if authentic events or exploration of topics/themes become a controller in learning activities. By participating in the exploration of these themes/events, students can simultaneously learn about the process and content of subjects. This is consistent with the opinion of Collin \& Dixen (1991): "Integrated learning occurs when an authentic event or exploration of a topic is the driving force in the curriculum. By participating in the event/topic exploration, students learn both the processes and content relating to more than a curriculum area at the same time."

From this statement, it is clear that as a trigger in the implementation of integrated learning is through the exploration of topics. In exploring the topic, a particular theme is raised. Learning activities take place around the theme and then discuss the main concepts related to the theme.

\section{Principles of Integrated Learning}

Integrated learning should not conflict with the applicable curriculum, but integrated learning must support the achievement of learning objectives contained in the curriculum. In general, the design of integrated learning refers to the following principles (Indrawati, 2009;2010):

- The substance of the material to be mixed into integrated learning is lifted from the fundamental concepts contained in the relevant aspects of development.

- Among the key concepts in question are related to meaning and function, which, when mixed into a particular context (event, issue, problem, or theme), still have an original meaning, in addition to having a meaning that develops in the context in question.

- Fun learning activities designed in integrated learning include aspects of child development, namely moral and religious values, language, physical, motor, and art.

\section{Characteristics of Integrated Learning}

As a learning model, integrated learning has its characteristics which are at the same time characteristic of the model, whose characteristics can be summarized as follows:

- Holistic (overall); This means a phenomenon that is the center of attention in integrated learning is observed and studied from several disciplines at once, not from a compartmentalized perspective. This is intended to train students to understand phenomena from all sides. 
- Meaningful; meaning meaningfulness in communicating with the relationship between the knowledge that students have had with the material being studied. Thus, the learning process is felt to be more meaningful for students. Real references from various concepts and linkages with other concepts will increase the meaningfulness of the concepts being studied so that in the end, students can apply their learning gains to solve real problems in their lives.

- Authentic; it means that students can directly understand the concepts and principles that they want to learn, through the results of interaction and learning from facts and events. Thus, information and knowledge obtained by students become more authentic.

- Active; it means students are actively involved in the learning process, both individually and in groups. In integrated learning, the desires, interests, and abilities of students are considered, so that students are motivated to search for information and knowledge in understanding the concepts being learned.

- Simplicity; that is, the material is presented simply, meaningfully, and easily understood, the reasonableness of the context, flexibility (according to local conditions and needs), integration, and the existence of various life skills.

- Natural; that is, integrated learning provides an environment that allows students to learn naturally, following the level of development of students who always experience the process and are not isolated from the natural environment.

In line with that, it is also stated that integrated learning has the following characteristics: (1) Child-centered, (2) Provide direct experience for children, (3) Separation between fields of study is not very clear, (4) Presenting concepts from various fields of study in a learning process, (5) flexible, and (6) Learning outcomes can develop according to the interests and needs of children. Integrated learning is not just about combining the contents of several subjects, but more broadly by combining various skills, attitudes, or other abilities so that learning is meaningful. Said to be meaningful because, in integrated learning, students understand the concepts learned through direct experience and relate them to other concepts that are already understood. The characteristics of integrated learning above are very much following the philosophy of constructivism as a reference for education that is now adopted, wherewith this philosophy, we must hold to the principle that students are active and can build their knowledge.

\section{Foundation for Integrated Learning Philosophy and Psychology}

A normative foundation requires that integrated learning should be carried out based on the ideal picture to be achieved by learning objectives. Whereas the practical foundation expects integrated learning to be carried out by taking into account practical situations and conditions that influence the possibility of its implementation achieving optimal results.

Learning psychological theories that also underlie integrated division, among them, are Piaget's theories. In this case, Piaget argues that children's intellectual development includes stages: (a) sensory-motor, (b) pre-operational, (c) concrete operational, and (d) formal operational (Indrawati, 2009). Early age children (2-8 years) are in the preoperational and concrete stages, so when we refer to this theory, in practice learning in the classroom, teachers should pay attention to the characteristics of child development at this stage. In particular, child education psychologists suggest that early childhood 
development is holistic, integrated child development, where aspects of development are closely related and affect other aspects of development. Physical development cannot be separated from mental, social, and emotional development or vice versa, and development will be integrated with experience, life, and the environment.

Based on Piaget's theory, it is clear that the integrated learning model is not only suitable for early age students (kindergarten or elementary school) but can also be implemented for students in junior high school and senior high school levels. This is because, in essence, the integrated learning model is a learning approach that allows students both individually and in groups to seek actively, explore, and discover concepts and principles holistically and authentically.

One of the basic requirements needed in the realization of integrated learning is the foresight of teacher professionalism in anticipating the use of various possible hook directions. The hook directions referred to are usually in the form of guiding questions that must be answered or assignments that must be done by students, which have an impact leading to the realization of conceptual links within the field of study (Tisno \& Ida, 2007). Furthermore, Tisno \& Ida (2007) explained that the other main requirement was material mastery of the subjects, concepts, skills in the field of study that needed to be linked, which teachers should have had. Therefore the expertise of a teacher is needed in realizing a learning experience that is more holistic and meaningful for students.

\section{Development and Implementation of Integrated Learning}

Various integrated learning models, as proposed by Fogarty (1991), are as many as ten integrated learning models. The ten integrated learning models are: 1) the fragmented model, 2) the connected model, 3) the nested model, 4) the sequenced model, 5) the shared model, 6) the webbed model, 7) the threaded model, 8 ) the integrated model, 9) the immersed model, and 10) the networked model.

From the ten integrated learning models above, three learning models were chosen that were considered appropriate and appropriate to be developed and could be easily implemented in primary education or at the level of junior high schools. The three integrated learning models in question are the connected model, the webbed model, the integrated model. The integrated learning process has three stages that are passed in each integrated learning process, namely: (1) the preparation phase; (2) implementation stage: (3) culmination stage.

Table 2. Model Connected.

\begin{tabular}{lll}
\hline \multicolumn{1}{c}{ Planning } & \multicolumn{1}{c}{ Implementation } & \multicolumn{1}{c}{ Culmination } \\
\hline - Concept map & $\bullet$ Execution of tasks & $\bullet$ Presentation of report \\
- The design of & $\bullet$ Analysis of the results of the & $\bullet$ Evaluation \\
learning activities & evaluation tasks & \\
& $\bullet$ Preparation of reports & $\bullet$ \\
\hline
\end{tabular}

Table 3. Model Webbed.

\begin{tabular}{lll}
\hline \multicolumn{1}{c}{ Planning } & \multicolumn{1}{c}{ Implementation } & \multicolumn{1}{c}{ Culmination } \\
\hline - Assessment of themes & - Information gathering & $\bullet$ Presentation of \\
- Setting theme & - Information processing & $\bullet$ Evaluation \\
- Development of sub-themes & - Preparation of reports & $\bullet$ \\
- Determination of learning & $\bullet$ & $\bullet$ \\
\hline
\end{tabular}


Table 4. Model Integrated.

\begin{tabular}{lll}
\hline \multicolumn{1}{c}{ Planning } & \multicolumn{1}{c}{ Implementation } & Culmination \\
\hline - $\begin{array}{l}\text { Concept maps of } \\
\text { various fields }\end{array}$ & - Execution of tasks & Presentation of \\
$\begin{array}{l}\text { Related } \\
\text { concepts }\end{array}$ & - Analysis of the results of the \\
$\begin{array}{l}\text { The design of learning } \\
\text { activities }\end{array}$ & - Preparation of reports \\
\hline
\end{tabular}

\section{Strengths and Weaknesses of Integrated Learning Strengths of Integrated Learning}

As it is known that no learning model is suitable for all concepts, a learning model must be adapted to the concept to be taught. However, the use of integrated learning models has several advantages compared to conventional approaches, among others (Indrawati, 2009):

- Learners' experiences and learning activities will always be relevant to their level of development.

- The selected activities can be adjusted to the interests and needs of students.

- All learning activities are more meaningful for students so that learning outcomes will last longer.

- Integrated learning fosters students' thinking and social skills.

- Integrated learning presents activities that are pragmatic with problems that are often encountered in the real-life / environment of students.

- If integrated learning is designed together, it can improve cooperation between teachers in related fields of study, teachers and students, students with students, students/teachers with resource persons, so that the learning process will be more fun, learning in more realistic situations, and more meaningful.

\section{Weaknesses of Integrated Learning}

In addition to having advantages, integrated learning also has limitations, especially in its implementation in the classroom, namely in the design and implementation of learning and evaluation, which requires many teachers to evaluate the process. Several limitations of integrated learning if applied at the junior or senior high school level, including:

- From the teacher aspect: Teachers must be broad-minded, have high creativity, good learning methodology skills, high confidence, and dare to package and develop material.

- From the aspect of students: Integrated learning requires the learning abilities of students who are "good," both in their academic abilities and creativity.

- From the aspect of learning tools and resources: Integrated learning requires considerable and varied reading material or sources of information, which may also be very much needed by the internet.

- From the curriculum aspect: The integrated curriculum must be flexible, oriented towards achieving students' understanding of completeness (not on achieving material targets).

- From the aspect of assessment: Integrated learning is very demanding that there is a comprehensive assessment (comprehensive), which determines the learning success of students from several fields of study to be integrated. 


\section{Implementation of Integrated Learning in the Curriculum in Indonesia}

Integrated thematic learning implemented in elementary schools in the Curriculum 2013 is based on Minister of Education and Culture Regulations Number 65 the Year 2013 concerning Basic and Secondary Education Process Standards, which state that "In accordance with Graduates Competency Standards and Content Standards, the learning principles are used from partial learning to integrated learning." The implementation of the Curriculum 2013 in elementary was carried out through learning with a thematicintegrated approach from grade I to grade VI.

- Integrated thematic learning approaches are given in elementary schools starting from grade I to grade VI

- The approach used to integrate basic competencies from various subjects, namely, intra-disciplinary, inter-disciplinary, multi-disciplinary, and trans-disciplinary. Intra Disciplinary is the integration of the dimensions of attitudes, knowledge, and skills as a whole in each subject that is integrated through the theme. Inter-Disciplinary is to combine the basic competencies of several subjects so that they are related to each other, as illustrated in the Natural Sciences and Social Sciences subjects, which are integrated into various other suitable subjects. This is reflected in the Elementary Curriculum Structure for Grade I-III, there are no natural science and social studies subjects, but the natural and social science content is integrated into other subjects, especially Indonesian. Multi-Disciplinary is an approach without combining basic competencies so that each subject still has its basic competencies. The illustration is a Natural Science and Social Sciences, which stands alone in grade IV-VI. TransDisciplinary is an approach in determining the theme that links the various competencies of the subjects with the problems that surround them.

- Integrated thematic learning is based on a combination of various processes of integration of various competencies.

- Integrated thematic learning is enriched by the placement of Indonesian subjects as advocates/tools/media for other subjects

Integrated thematic learning is integrated learning that uses themes to link several subjects to provide meaningful experiences to students. The use of themes is expected to provide many benefits, including:

- Learners easily focus on a particular theme;

- Students can learn knowledge and develop various basic competencies between subjects in the same theme;

- Students understand the subject matter more deeply and impressively;

- Students can have better basic competencies because they relate subjects to students' personal experiences;

- Students can better feel the benefits and meaning of learning because the material is presented in the context of a clear theme;

- Students are more passionate about learning because they can communicate in real situations, to develop an ability in one subject while learning other subjects;

- The teacher can save time because the subjects presented thematically can be prepared at once and given in two or three meetings, the rest of the time can be used for remedial activities, strengthening, or enrichment.

Pedagogically, thematic learning is based on an exploration of knowledge and values learned through themes so that students have a complete understanding. Students are 
positioned as explorers so that they can discover relationships and patterns that exist in the real world in relevant contexts. Thematic learning is intended to develop a variety of abilities, skills, and attitudes obtained through the thematic learning process integrated into the real-world context that is brought into the learning process creatively.

\section{Principles of Integrated Thematic Learning}

Integrated thematic learning has the following principles:

- Students find out, not told.

- The separation between subjects becomes less visible. The focus of learning is directed to the discussion of competencies through themes that are closest to the lives of students.

- Some themes unite several basic competencies related to various concepts, skills, and attitudes.

- Learning resources are not limited to books.

- Students can work independently or in groups according to the characteristics of the activities carried out.

- Teachers must plan and carry out learning to accommodate students who have different levels of intelligence, experience, and interest in a topic.

- Basic Competencies subjects that cannot be integrated can be taught individually.

- Provide direct experience to students (direct experiences) of things that are concrete to the abstract.

\section{Integrated Thematic Learning Design}

First, review the syllabus. In the context of implementing thematic integrated learning, educators need to conduct an assessment of the syllabus that has been prepared before developing it into a lesson plan that will be used in school activities. The syllabus review activity aims to find out, among other things, the relationship between subthemes and the competencies of the subjects to be learned and the learning activities developed. Through this syllabus review activity, it is expected that the teacher will also obtain some information, including (1) availability of themes and sub-themes, (2) distribution of basic competencies on themes (mapping), and (3) development of indicators on each theme (the network of indicators on themes ).

Second, develop Lesson Plan (LP). The syllabus is used as a reference in developing learning implementation plans. Developing or developing lesson plans is a planning step that must be done by every teacher. RPP is a plan of face-to-face learning activities for one meeting (one day). The lesson plan is developed from the syllabus by paying attention to student books and teacher books that have been prepared by the Ministry of Education and Culture.

The lesson plans are arranged completely and systematically so that learning takes place interactively, inspirational, fun, challenging, efficient, motivating students to participate actively, and provide sufficient space for the initiative, creativity, and independence following their talents, interests, and physical and psychological development learners. The principles in preparing the lesson plan include the following matters.

- Pay attention to students' differences such as initial abilities, intellectual level, talents, potential, interests, learning motivation, social abilities, emotions, learning styles, 
special needs, learning speed, cultural background, norms, values, and/or the environment of students.

- Encourage children to participate actively.

- Use learner-centered principles to encourage enthusiasm for learning, motivation, interest, creativity, initiative, inspiration, innovation, and independence.

- Developing a culture of reading, writing, and arithmetic

- Provide feedback and follow-up for strengthening, enrichment and remedial purposes

- Accommodating thematic-integrated learning, integration across subjects, aspects of learning, and cultural diversity.

- Emphasize the use of information and communication technology in an integrative, systematic, and effective manner following the situation and conditions.

Integrated thematic learning needs to pay attention to approaches, strategies, models, and learning methods. The approach can be interpreted as a starting point or our perspective on the learning process. Educator-centered approaches reduce direct learning strategies, deductive learning, or expository learning. Meanwhile, learning approaches that are centered on learners reduce discovery and inquiry learning strategies and inductive learning strategies. The strategy of art uses skills and resources to achieve its goals through effective relationships with the environment and the most favorable conditions. Learning models are plans (patterns) that can be used to shape the curriculum, design teaching materials, and guide teaching, whereas the method is the description of the approach. One approach can be translated into various methods. The method is a learning procedure that is focused on achieving goals.

In Curriculum 2013, the learning approach uses an integrated thematic approach and a scientific approach. Strategies for integrated thematic learning are active student learning. The integrated thematic learning model uses the spider web model. The method in the form of a project method whose learning is done inside or outside the classroom involving students to carry out activities that integrate various competencies and subjects. The activity must involve a variety of skills such as physical, intellectual as well as subjects and competencies that include attitudes, knowledge, and skills. The implementation of integrated learning is carried out in the opening, core, and closing stages. At the core activity, all learning activities include observing, questioning, collecting data, associating, and communicating.

In observing activities, students learn to capture phenomena or information about objects, humans, nature, activities, and ideas through an immediate sensing process or objective sensing. For example: seeing, listening, listening, feeling, reading, and manipulating. The questioning activity encourages students to ask questions from factual to hypothetical, beginning with the teacher's guidance to being independent (becoming basic) to explore information or meaning of something through a dialectical questioning process by asking several tracking questions (probing question), for example asking questions: What, Where, Who, When, Why, How, How, and so on.

Associate activities emphasize learning activities for students to carry out a process of understanding (comprehension) to obtain/get meaning/understanding of facts, symptoms, activities, ideas, values, etc. (acquiring and integrating knowledge) through activities: differentiating, comparing, analyzing data in the form of making categories, determining data/category relationships, concluding from the results of data analysis, etc. starting from unstructured - unstructured - multi-structure - complicated structure. 
Communicating activities emphasize learning activities of students to present ideas, models,/creative products and provide explanations/demonstrate the results of problem-solving, development, new ideas, conclusions in oral form, writing, diagrams, charts, pictures, or other media in the classroom/outside the classroom.

In carrying out activities with a scientific approach, educators need to prepare various activities that are appropriate to the characteristics of elementary school-age children. Description of the development of elementary school-age children for physical aspects, especially in the dimensions of height and weight in general, according to F.A. Hadith, the physical growth of elementary school-age children tends to be slower and more consistent when compared with the early age. The average elementary school-age child experiences a weight gain of around $2.5-3.5 \mathrm{~kg}$ and an additional height of $5-7 \mathrm{~cm}$ per year.

As for the development of motor skills in general: (1) Child agility increases, (2) Can play bicycle, (3) Already know right and left, (4) Start reading smoothly, (5) Increased interest in the spiritual field, (6) The speed and smoothness of motor activity increases, and (7) Able to use household appliances.

Early childhood cognitive development includes (1) Pleasing to produce something and correcting oneself, (2) Beginning to get to know the wider world, (3) Slightly imagining, (4) Increasing curiosity, (5) Able to adapt to several the conditions encountered, (6) Problems with abstract conditions, large numbers, periods and space. The characteristics possessed by elementary school-age children in general are:

- It is nice to move. Unlike adults who like to sit for hours, elementary school-age children prefer to move. Children of this age can sit quietly for a maximum of about 30 minutes.

- Enjoy playing. The world of children is indeed a world of play that is full of excitement, as well as children of elementary school age, and they are still very happy to play - especially low-grade elementary school children.

- It is good to do something directly. Elementary school-age children will more easily understand the lessons given by the teacher if he can directly practice the lessons themselves.

- Enjoy working in groups. At elementary school age, children begin to socialize intensely. Association with peer groups will make elementary school children can learn many things, for example, loyal friends, work together, and compete healthily.

Based on the characteristics of the early grades, educators need to prepare various activities/activities that are suitable and appropriate. Various activities that can be carried out following the stages of early grade child development (grade I-III) are:

- Children recognize something based on what they hear because the teacher can read texts or stories.

- A 7-year-old child is a good listener, so the teacher allows the child to listen.

- An 8-year-old child "likes to cooperate," the teacher can give assignments to do group activities.

- 9-year-old children have the trait of "little imagination," and therefore, in observing activities, teachers need to encourage children to be able to imagine.

- The teacher gives opportunities and prepares activities that children can do outside the room with friends and alone in the room.

- The teacher prepares activities that encourage children to move in a direction to hone their skills. 
- Children need to be allowed to hone their physical skills so that they can develop gross motor skills, for example, through various activities of walking, running, jumping, throwing, and for fine motor skills by allowing children to write, draw, cut.

- The teacher allows children to actively carry out their activities without example.

- For 8-year-old children, teachers can prepare various activities that encourage children to talk actively because they like to exaggerate in talking.

- Allow children to be speakers, for example, convey the results of their activities, comment on something, and so on.

- Allow children to have discussions or questions and answer activities in pairs because, in general, they also like to dialogue or have conversations in pairs.

- The teacher prepares activities that encourage children to speak descriptive words, for example, telling the experience they experienced.

- Teachers need to prepare activities that encourage children to speak actively even when speaking at this age children can exaggerate in their speech, and the development of vocabulary is speedy.

- Encourage children to report their work verbally because, in general, they are good speakers and have rapid vocabulary development.

- For early grades, the teacher can encourage children to communicate in various forms of complete pictures (e.g., human images can be complete), coloring pictures with natural colors/natural resembling the original color.

- Teachers need to warn early-age children often to be more careful in doing assignments because, in general, they move quickly and work in a hurry because they are full of energy.

- Teachers need to prepare various activities carried out not only indoors but also outdoors because children at this age need to release energy physically (outdoor activities).

- Teachers need to arrange activities that do not require long concentration because children at this age have limited concentration.

- The teacher needs to prepare a fun activity because, at this age, his social development is still very good and full of humor.

- Teachers need to prepare activities that allow children to collaborate specifically with peers.

- Limits or rules need to be arranged in such a way because children are still having problems with rules and restrictions.

- Teachers need to prepare various activities that produce something because, at this age, they like to produce work.

- Teachers also prepare activities in the form of concrete operations because, at this time, they are still in trouble with abstract conditions.

- This child is not a good listener because when he listens, he will be filled with ideas so that sometimes he cannot remember what he has said.

- Encouraging children to express descriptively, for example, telling the experiences they experienced.

- Prepare various exploratory activities such as looking for facts in a dictionary, investigating the environment, to be able to get to know the wider world.

\section{Problems of Implementing the Curriculum 2013}

Curriculum 2013 is often called the character-based curriculum. What is Curriculum 2013? This curriculum is a new curriculum issued by the Ministry of Education and 
Culture of the Republic of Indonesia. The Curriculum 2013 itself is a curriculum that emphasizes understanding, skill, and character education, where students are required to understand the material, be active in the process of discussion and presentation, and have good manners and high discipline. This curriculum officially replaced the Education Unit Level Curriculum, which was implemented since the year 2006. In general, the Curriculum 2013 leaves various deficiencies, including the following:

- The Curriculum 2013 contradicts Law Number 20 the Year 2003, which contains the National Education System. This is because the emphasis on curriculum development is only based on aspects of pragmatic orientation. Besides, the Curriculum 2013 itself is not based on evaluation aspects of the implementation of the Education Unit Level Curriculum (KTSP) system in 2006 so that in its implementation, it can confuse teachers and education stakeholders.

- Teachers, as an important element, have also never been directly involved in the process of developing the Curriculum 2013. The government sees as if the teacher and students have the same capacity.

- There is no balance between the orientation of the learning process and the results in the Curriculum 2013 itself. Balance is difficult to achieve because policies on the national exam (NE) are still in effect. The national examination is only able to encourage educational orientation on results and does not pay attention to the learning process. This will have an impact on the exclusion of subjects that are not tested in the NE. Non-NE subjects are also able to make a significant contribution to realizing educational goals.

- The government integrates the subject of Natural Sciences with Social Sciences in Indonesian subjects for the level of basic education.

Problems that arise from the implementation of the Curriculum 2013

- Many teachers are mistaken because they think that with the Curriculum 2013, the teacher does not need to explain the material to students in the class, even though many subjects must still have an explanation from the teacher.

- Many teachers are not ready mentally with this Curriculum 2013, because this curriculum requires teachers to be more creative very few teachers are like that, so it takes a long time to be able to open the horizons of teacher thinking. One of them with training and education to change the paradigm of the teacher as a provider of material into a teacher who can motivate students to be creative.

- Lack of teacher understanding with the concept of a scientific approach

- Lack of teacher skills in designing lesson plans

- There are not many teachers who master authentic assessment

- Teachers have never been directly involved in the Curriculum 2013 development process because the government tends to see teachers and students having the same capacity.

- There is no balance between the orientation of the learning process and the results in the Curriculum 2013 because the NE is still a limiting factor.

- Too much material must be mastered by students so that not every material can be appropriately conveyed, not to mention the problem of the teacher is less dedicated to the subjects he is capable of.

- Student and teacher learning burdens are too heavy, so school time is too long.

- Most teachers are still accustomed to using conventional methods.

- Mastery of technology and information for learning is still limited. 
- The teacher does not always change.

- Lack of teacher ability in the process of assessing attitudes, skills, and knowledge holistically.

- Creativity in syllabus development is reduced.

- School autonomy in curriculum development is reduced.

- Schools are not independent in addressing the curriculum.

- The level of student activity has not been evenly distributed.

- KBM is generally currently conventional.

- Not all teachers understand the attitude and skills assessment system.

- Increase teacher workload.

- The image of schools and teachers will decrease if they fail to implement the Curriculum 2013.

\section{The Impact of Implementing the Curriculum 2013 on Teachers}

The change of KBK (Curriculum Based Competency) to Curriculum 2013 has been carried out for some selected education units. Implementation of the Curriculum 2013 provided much homework to the Ministry of Education and Culture. The main problems in implementing curriculum are the readiness of the mindset of the teacher, the reduction of teacher's lesson hours, the lack of guidelines, and the incompatibility of the contents of the book with the new curriculum. The teacher must continue to be nurtured and trained not only during preparation but during implementation through continuous assistance to change this mindset. From the teacher's point of view, teachers are also required to be sensitive to change and have a high spirit of initiative. The teacher must practice being able to solve the problems that will be encountered in the implementation of this new curriculum. Curriculum changes that make less and even the loss of teaching hours do not dampen the teacher's enthusiasm for teaching. The education unit must be active and creative in managing this teacher's teaching hours so that the principles of fairness and fulfillment of teaching hours requirements can be met. The lack of prepared guidelines is a separate homework for the government. The government must immediately prepare these deficiencies. The problem of book incompatibility must also be immediately followed up, and the teacher must actively participate in filtering out the substance contained in the book, especially those given to students so that there is no mistake of students' understanding of the material presented.

For the government, it is necessary to conduct a more in-depth study regarding the development of a broader curriculum, taking into account the geographical conditions of Indonesia. Do not let the new curriculum can only be applied in large cities but must be able to embrace the entire territory of Indonesia, bearing in mind that now trials are only carried out in big cities. The curriculum is a bridge in the success of education as the basic capital of national development, for that its implementation needs to be guarded, criticized, and continuously evaluated with all its advantages and disadvantages. With the support and strong foundation of the government, DPRRI, and the community through the implementation of the Curriculum 2013, the educational objectives can be achieved well.

\section{CONCLUSIONS}

An integrated curriculum is an educational approach that prepares students to face lifelong learning. In curriculum integration, schools must view education as a process of 
developing the abilities needed in life, especially in facing 21st-century life challenges, not discrete subjects that are divided into different fields. This integrated learning model has strengths/strengths, which makes it easier for students to link or connect various concepts, skills, abilities, which exist in various fields of study. This allows understanding across fields of study or subjects. If this model is implemented correctly, then this model will also integrate the learning environment so that student motivation increases. While the weakness is that this model is challenging to implement in full. This model requires special skills, in addition to planning, it is necessary to change the lesson schedule that is tailored to the choice of themes/topics that are integrated by the teacher or the teacher team. Recommendations: The integrated curriculum developed by Robin Fogarty has many advantages that can be adapted in the development of education in Indonesia, including the revised Curriculum 2013. Academics and practitioners must comprehensively understand the nature of the ten curriculum models (Robin Fogarty) and the Curriculum 2013 before making tools and implementing them in learning.

\section{ACKNOWLEDGMENTS}

The researcher thanks Prof. Dr. Prabowo and Prof. Dr. Suyono, for all the positive feedback.

\section{REFERENCES}

BNSP. (2006). Panduan penyusunan kurikulum tingkat satuan pendidikan jenjang pendidikan dasar dan menengah. Jakarta: Depdiknas.

Collin, G. \& Dixen. (1991). Integrated learning planned curriculum units. Canberra: Bookshelf Publishing.

Costley, K.C. (2015). Research supporting integrated curriculum: Evidence for using this method of instruction in public school classrooms. Running Head: Integrated Curriculum, 1-11.

Puspita, D. N., \& Widodo, W. (2013). Penerapan pembelajaran IPA terpadu dengan pendekatan contextual teaching and learning (CTL) materi bunyi dan pendengaran pada siswa SMP. Jurnal Pendidikan Sains e-Pensa, 1(2), 188-193.

Drake, B.S.M., \& Reid, J. (2010). Integrated curriculum. The Literacy and Numeracy Secretariat, 28, 5-8.

Duiningrum, I. (2018). Pengembangan perangkat pembelajaran IPA terpadu model nested untuk meningkatkan kemampuan kognitif, rasa ingin tahu dan keterampilan mengorganisasi ide peserta didik SMP. E-Journal Pendidikan IPA, 1, 27-32.

Fogarty, R., \& McTighe, J. (2015). Educating teachers for higher order thinking: The threestory intellect. Theory into Practice, 32(3), 161-169.

Fogarty, R. (1991). Ten ways to integrate curriculum. Educational Leadership, 49(2), 6165.

Fogarty, R. (1991). The mindfull school: How to integrate the curricula. Illinois: IRI/Skylight Publishing.

Glatthorn, A.A. (1994). Developing a quality curriculum. Virginia: Association for Supervision and Curriculum Development. Pitt St.

Hasnawati. (2013). Sistem pembelajaran terpadu di sekolah. Marwah, 12(1), 1-13.

Indrawati. (2009). Model pembelajaran terpadu di sekolah dasar. Bandung: PPPPTK IPA. Indrawati. (2010). Model Pembelajaran IPA Terpadu untuk SMP. Bandung: PPPPTK IPA. 
Kementerian Pendidikan dan Kebudayaan. (2013). Modul pelatihan implementaasi kurikulum 2013. Jakarta: Badan Pengembangan Sumber Daya Manusia Pendidikan dan Kebudayaan dan Penjaminan Mutu Pendidikan.

Kementerian Pendidikan Nasional. (2013). Peraturan menteri pendidikan nasional nomor 41 tahun 2007 tentang standar proses untuk satuan pendidikan dasar dan menengah. Jakarta: Kemendikbud.

Kim, M., \& Aktan, T. (2014). How to enlarge the scope of the curriculum integration of mathematics and science (CIMAS): A Delphi study. Eurasia Journal of Mathematics, Science and Technology Education, 10(5), 455-469.

Kiray, S.A. (2012). A new model for the integration of science and mathematics: the balance model. Energy Education Science and Technology Part B: Social and Educational Studies, 4(3).1181-1196.

Rahmanto, K.F., \& Masykuri, W.S.M. (2015). Pengembangan modul IPA terpadu berbasis inkuiri terbimbing dengan tema keju untuk meningkatkan keterampilan proses sains dan hasil belajar siswa smp kelas VII. Jurnal Inkuiri, 4(4)109-120.

Kurt, K., \& Pehlivan, M. (2013). Integrated programs for science and mathematics: review of related literature. International Journal of Education in Mathematics, Science, and Technology, 1(2), 116-121.

Draghicescu, L.M., Gorghiu, G., \& Gorghiu, A.M.P.L.M. (2013). Pleading for an integrated curriculum. Journal of Science and Art, 1(22).89-95.

Makhrus, M., \& Prayitno, G.H. (2012) Penerapan perangkat pembelajaran fisika berorientasi pembelajaran ipa terpadu tipe connected. Jurnal Pendidikan dan Pembelajaran, 19(2). 237-242.

Mc Bee, R.H. (2016). Why teachers integrate. Educational Forum, 64(3), 254-260.

Muhafid, E.A., \& Dewi, N.R. (2013). Pengembangan modul IPA terpadu berpendekatan keterampilan proses pada tema bunyi di SMP kelas VIII. Unnes Science Education Journal, 2(1), 140-148.

Olivia, P.F. (1992). Developing the curriculum. New York: Harper Collins Publisher.

Palmer, J.M. (1991). Planning wheels turn curriculum around. Educational Leadership Journal. 29(2), 57-60.

Rahmatika, R. (2016). Pengembangan perangkat pembelajaran IPA dengan pendekatan scientific pada materi sistem eksresi untuk melatihkan keterampilan berpikir kritis siswa SMP. Jurnal Pena Sains, 3(2), 102-108.

Rahmatika, R., \& Ismono, M.B. (2013). Perangkat pembelajaran IPA terpadu tipe webbed pada tema pengolahan minyak kelapa untuk siswa SMP kelas VIII. Jurnal Pendidikan Sains e-Pensa, 1(2), 30-34.

Hapsari, S.I., \& Hariyono, T.P.E. (2013). Pengembangan lembar kerja kegiatan siswa (LKS) IPA terpadu berbasis guided discovery pada tema mitigasi bencana untuk siswa kelas VII SMP. Jurnal Pendidikan Sains (JPS) e-Pensa, 1(3), 28-33.

Mansurotun, S., Astriani, D., \& Sanjaya, I.G.M. (2014). pengembangan perangkat pembelajaran IPA terpadu tipe webbed berorientasi inkuiri terbimbing tema rainbow cake untuk siswa SMP/ MTs kelas VIII. Jurnal Pendidikan Sains e-Pensa, 2(1), 111-116.

Sukartiningsih, W. (2016). Validity teaching materials of Indonesian education in beginning class of elementary school course based integrated science and social studies. Journal of Education, Teaching and Learning, 1(2), 82-88.

Supriatin, A. (2008). Peningkatan kemampuan koneksi matematis melalui pembelajaran tematik. Edusains, 1(2), 1-24. 
Wiyono, Y.S.O. (2013). Pengembangan perangkat pembelajaran IPA terpadu tipe shared pada materi molekul dan perubahan energi dalam metabolisme tumbuhan hijau kelas VIII. Jurnal Pendidikan Sains (JPS) e-Pensa, 1(1), 35-41.

Tisno, H.S., \& Ida S.H. (2007). Pembelajaran Terpadu D-II PGSD. Jakarta: Universitas Terbuka.

Zais, R.S. (1976). Curriculum, principles, and foundation. New York: Harper \& Raw Publisher.

\section{Authors:}

Erwin Akib, M, Pd., Ph.D

Muhammadiyah University Makassar, Makassar, Indonesia

Jl. Sultan Alauddin No.259, Gn. Sari, Kota Makassar, Sulawesi Selatan 90221, Indonesia

Email: erwin@unismuh.ac.id

"Muhammad Erwinto Imran (Corresponding Author)

Muhammadiyah University Makassar, Makassar, Indonesia

Jl. Sultan Alauddin No.259, Gn. Sari, Kota Makassar, Sulawesi Selatan 90221, Indonesia

Email: erwinto@unismuh.ac.id

\section{Saiyidah Mahtari, M.Pd}

Lambung Mangkurat University, Banjarmasin, Indonesia

Jl. Brigjen H. Hasan Basri, Pangeran, Kota Banjarmasin, Kalimantan Selatan 70123, Indonesia

Email: saiyidah_pfis@ulm.ac.id

\section{Muhammad Rifqi Mahmud, M.Pd}

UIN Sunan Gunung Djati, Bandung, Indonesia

Jl. A.H. Nasution No.105, Cipadung, Kec. Cibiru, Kota Bandung, Jawa Barat 40614, Indonesia

Email: m.rifqi.mahmud@uinsgd.ac.id

\section{Anggy Giri Prawiyogy, S.Pd.., M.Pd}

Buana Perjuangan University, Karawang, Indonesia

Jalan Ronggo Waluyo Sirnabaya, Puseurjaya, Kabupaten Karawang, Jawa Barat 41361, Indonesia

Email: anggy.prawiyogi@ubpkarawang.ac.id

\section{Irfan Supriatna, S.Pd., M.Pd}

Universitas Bengkulu, Bengkulu, Indonesia

Jl. WR. Supratman, Kandang Limun, Kec. Muara Bangka Hulu, Sumatera, Bengkulu 38371, Indonesia

Email: irfansupriatna@unib.ac.id

\section{MT. Hartono Ikhsan, M.Pd}

STKIP Sebelas April Sumedang, Sumedang, Indonesia

Jl Jl. Angkrek Situ No.19, Situ, , Kabupaten Sumedang, Jawa Barat 45323, Indonesia

Email: mt_hartono@stkip11april.ac.id 